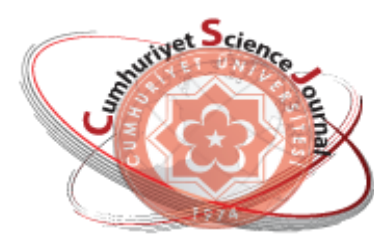

e-ISSN: $2587-246 X$

ISSN: 2587-2680

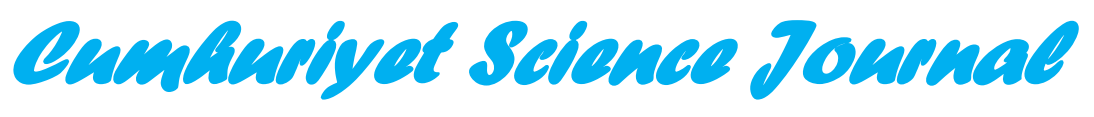

$\cos 7$

Cumhuriyet Sci. J., Vol.38-4 (2017) 759-769

\title{
Experimental and Theoretical Investigations of Molecular Structure and Vibrational Frequencies of Hypericin Molecule
}

\author{
Tuba OZDEMIR ${ }^{1 *}$, Halil GOKCE ${ }^{2}$ \\ ${ }^{1}$ Bartın University, Vocational School of Health Services, 74100 Bartın, Turkey \\ ${ }^{2}$ Giresun University, Vocational School of Health Services, 28200 Giresun, Turkey \\ Received: 31.01.2017; Accepted: 17.07.2017 \\ http://dx.doi.org/10.17776/csj.340497
}

\begin{abstract}
In the present study, vibrational analysis of hypericin molecule was experimentally performed using FT-IR spectroscopy. The molecular structure, geometric parameters, vibrational wavenumbers, molecular electrostatic potential and the highest and the lowest occupied molecular orbital analyses of hypericin molecule were theoretically obtained with Density Functional Theory. The vibrational wavenumbers were consistent with literature and the experimental data obtained in the current study.
\end{abstract}

Keywords: Hypericin, Vibrational Spectra, DFT, HOMO and LUMO analyses, MEP surface.

\section{Hypericin molekülünün Moleküler Yapısı ve Titreşim Frekanlarının Deneysel ve Teorik olarak İncelenmesi}

Özet: $\mathrm{Bu}$ çalışmada hiperisin molekülünün titreşim analizi FT-IR spektroskopisi ile deneysel olarak gerçekleştirildi. Aynı zamanda, hiperisin molekülünün moleküler yapısı, geometrik parametreleri, titreşim dalgaboyları, moleküler elektrostatik potansiyeli ile en yüksek ve en düşük dolu orbital (HOMO-LUMO) analizleri Yoğunluk Fonksiyonel Teorisi ile teorik olarak elde edildi. Titreşim dalgaboylarının literatür verileri ve mevcut çalışmadan elde edilen deneysel sonuçlarla tutarlı olduğu gözlemlendi.

Anahtar Kelimeler: Hiperisin, Titreşim Spektrumları, DFT, HOMO ve LUMO analizleri, MEP yüzeyi.

\section{INTRODUCTION}

Hypericum perforatum $\mathrm{L}$. is a herbal medicine which is named as St. John's Wort (SJW) and used for psychiatric disorders, wounds, and inflammation. In addition to the treatment of depression [1-3], SJW also exhibits antiinflammatory $[4,5]$ and analgesic effects $[6,7]$.

Lee et al., [8] investigated the effects of acylphloroglucinols on CYP3A4 enzyme activity to examine their roles in herb-drug interaction. Siskos et al., [9] investigated the Proton NMR chemical shift assignment of hypericin using DFT calculations. Öztürk et al., [10] evaluated the wound-healing capability of St. John's Wort on chicken embryos. Zhang et al., [11] evaluated a complex of hypericin with $\beta$-cyclodextrin.

St. John's wort herb extract, was traditionally obtained using different solvents and with or without antioxidants [12]. GÎTEA et al., [13] analyzed the extracts of hypericum species by UV/VIS. Derun et al., [14] performed the extraction and analysis of Hypericum perforatum L. using GC-MS and LC-MS. Nikolic et al., [15] investigated St.John's wort as an antibiotic. Hasanein et al., [16] investigated the effect of this molecule on memory impairment in rats.

Hypericum perforatum L. is a medicinal plant [17]. Most of the constituents in Hypericum 
perforatum $\mathrm{L}$. have displayed diverse therapeutic and biological effects [18]. The polycyclic bianthrone, hypericin, from the medicinal plant Hypericum (Hypericaceae), was found to have antiviral activity against numerous membranecontaining viruses [19,20]. Hypericin and hyperforin are among the most active constituents in SJW [21]. Among other constituents, naphthodianthrones and phloroglucinols have shown interesting pharmacological properties as reported by Wölfle et al. [22].

The vibrational wavenumbers of hypericin, an active constituent of Hypericium, were studied in this research. The recorded experimental data (FTIR) were supported with parameters which were computed using theoretical methods (DFT / B3LYP / 6-311++G(d,p)). The calculated and experimental results were used to give detailed information of the molecular structure of hypericin. Furthermore, the dipole moment, HOMO and LUMO shapes and energies as well as the MEP surface of the hypericin were investigated with the aforementioned computational level. The structural characteristics of the title molecule were specified. Its vibrational frequencies, other interactions between the atoms, optimization steps, structural parameters and energies were also examined.

\section{EXPERIMENTAL DETAILS}

In the present study, Hypericin was obtained from Sigma-Aldrich Corporation. FT-IR spectrum of Hypericin from Hypericum perforatum molecule was recorded in 400-4000 $\mathrm{cm}^{-1}$ region, using $\mathrm{KBr}$ pellet, on Fourier Transform Infrared spectrometer.

\section{COMPUTATIONAL PROCEDURES}

The molecular geometry, vibrational wavenumbers, HOMO and LUMO analyses and MEP map of the Hypericin molecule were evaluated with DFT / B3LYP / 6-311++ G(d,p) [23,24]. Molecular properties including geometric parameters and vibrational wavenumbers were investigated using GaussView and Gaussian 09W programs [25-27]. The Raman activities evaluated with the Gaussian09 software were converted to corresponding Raman intensities with the following equation,

$$
I_{i}=\frac{f\left(v_{0}-v_{i}\right)^{4} S_{i}}{v_{i}\left[1-\exp \left(-h c v_{i} / k T\right)\right]}
$$

where $v_{0}\left(\mathrm{~cm}^{-1}\right)$ is the frequency, $v_{\mathrm{i}}$ is the vibrational wavenumber, $\mathrm{h}$ and $\mathrm{k}$ are Planck and Boltzman constants, $\mathrm{T}$ is the temperature in Kelvin, $\mathrm{c}$ is the speed of light, and $\mathrm{f}$ is the scaling factor. $S_{i}$ represents the Raman activities and $I_{i}$ represents the Raman intensities [28-31].

\section{RESULTS AND DISCUSSIONS}

\subsection{Analysis of Molecular Structure}

Hypericin's empirical formula is $\mathrm{C}_{30} \mathrm{H}_{16} \mathrm{O}_{8}$. The structure of hypericin is composed of eight conjugated rings and it has methyl and hydroxyl substitutions as shown in Figure 1. The optimized molecular structure was obtained with B3LYP/6$311++\mathrm{G}(\mathrm{d}, \mathrm{p})$ level of the hypericin molecule (Figure 1). The molecular energy and dipole moment values calculated with the B3LYP/6$311++\mathrm{G}(\mathrm{d}, \mathrm{p})$ level are -1755.21315427 a.u. and 1.5462 Debye, respectively. The bonds lengths and angles were obtained using the B3LYP basis set as given in Table 1 .

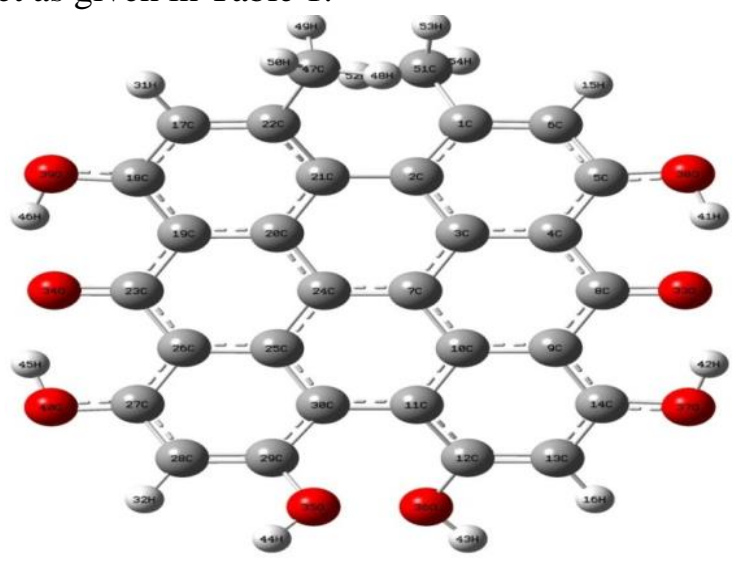

Figure 1. Hypericin's optimized molecular structure.

The C-C bond lengths were theoretically obtained between $1.383 \AA-1.432 \AA$ for the hypericin molecule. The $\mathrm{C}-\mathrm{O}$ bond length of hypericin molecule is about $1.333 \AA-1.353 \AA$. The $\mathrm{C}(23)=\mathrm{O}(34)$ and $\mathrm{C}(8)=\mathrm{O}(33)$ bond lengths were found at $1.274 \AA$. Likewise, hydroxyl groups' O - 
$\mathrm{H}$ bond lengths vary from $0.992 \AA$ to $0.995 \AA$. H46...O34, H45... $34, \mathrm{H} 41 \ldots \mathrm{O} 33$ and $\mathrm{H} 42 \ldots \mathrm{O} 33$ intra-molecular hydrogen bonding lengths are calculated as $1.657,1.639,1.657$ and $1.639 \AA$, respectively. $\mathrm{C} 22-\mathrm{C} 47\left(\mathrm{C}-\mathrm{CH}_{3}\right)$ and $\mathrm{C} 1-$ $\mathrm{C} 51\left(\mathrm{C}-\mathrm{CH}_{3}\right)$ bonds that are the longest bond lengths in hypericin molecule are computed as $1.515 \AA$ with mentioned computational level. The bond angles H-O-C and O-C-C obtained by DFT vary between $106.66^{\circ}$ and $122.82^{\circ}$, respectively. The calculated bond angles of $\mathrm{C} 47-\mathrm{C} 22-\mathrm{C} 17$, C47-C22-C21, C51-C1-C2 and C51-C1-C6 are $116.38^{\circ}, \quad 123.45^{\circ}, \quad 123.45^{\circ}$ and $116.39^{\circ}$, respectively at the $\mathrm{B} 3 \mathrm{LYP}$ level. The largest bond angles were found in $\mathrm{C} 47-\mathrm{C} 22-\mathrm{C} 21$ and $\mathrm{C} 51-\mathrm{C} 1-$ $\mathrm{C} 2$ angles with $123.45^{\circ}$ (cal.) and in O38-C5-C4 with $122.83^{0}$ (cal.) values. Additionally, the bond angles of O-C-C-C and C-C-C-C vary from $-177.33^{0}$ to $177.03^{0}$ and from $-32.39^{0}$ to $155.73^{0}$, respectively. The bond angles of $\mathrm{C} 47-\mathrm{C} 22-\mathrm{C} 21$ and $\mathrm{C} 51-\mathrm{C} 1-\mathrm{C} 2$ were theoretically found as $123.45^{\circ}$. We can see form the optimized molecular geometric form that the hypericin molecule is non planar. Out of plane deviations were observed in the region that hydroxyl and methyl groups were. For example, as given in Table 1, C1-C2-C21C22, C2-C21-C22-C47, C21-C2-C1-C51, C27$\mathrm{C} 28-\mathrm{C} 29-\mathrm{O} 35, \mathrm{C} 11-\mathrm{C} 30-\mathrm{C} 29-\mathrm{O} 35, \mathrm{C} 14-\mathrm{C} 13-$ C12-O36, C30-C11-C12-O36 and C12-C11-C30$\mathrm{C} 29$ dihedral angles are calculated as $-32.39^{\circ}$, $19.04^{0},-18.85^{0}, 168.32^{0}, 14.61^{0}, 198.33^{0}, 14.58^{0}$ and $29.00^{\circ}$, respectively.

Table 1. The computed molecular geometrical parameters of hypericin

\begin{tabular}{|c|c|c|c|}
\hline Bond length $(\AA)$ & \multicolumn{2}{|c|}{ The calculated Bond angles $\left({ }^{\circ}\right)$} & The calculated \\
\hline C18 - O39 & 1.336 & C-C-C (aromatic) & $116.30-124.05$ \\
\hline $\mathrm{C} 27-\mathrm{O} 40$ & 1.333 & H46 - O 39 - C18 & 106.82 \\
\hline $\mathrm{C} 29-\mathrm{O} 35$ & 1.353 & $\mathrm{H} 45-\mathrm{O} 40-\mathrm{C} 27$ & 106.66 \\
\hline $\mathrm{C} 12-\mathrm{O} 36$ & 1.353 & H44 - O35 - C29 & 109.66 \\
\hline C14 - O37 & 1.333 & H43 - O36 - C12 & 109.66 \\
\hline $\mathrm{C} 5-\mathrm{O} 38$ & 1.335 & H42 - O37 - C14 & 106.66 \\
\hline $\mathrm{C} 23=\mathrm{O} 34$ & 1.274 & $\mathrm{H} 41-\mathrm{O} 38-\mathrm{C} 5$ & 106.83 \\
\hline $\mathrm{C} 8=\mathrm{O} 33$ & 1.274 & $\mathrm{O} 39-\mathrm{C} 18-\mathrm{C} 17$ & 118.16 \\
\hline $\mathrm{C} 22-\mathrm{CH}_{3}$ & 1.515 & $\mathrm{O} 39-\mathrm{C} 18-\mathrm{C} 19$ & 122.82 \\
\hline $\mathrm{C} 1-\mathrm{CH}_{3}$ & 1.515 & $\mathrm{O} 34-\mathrm{C} 23-\mathrm{C} 19$ & 120.57 \\
\hline $\mathrm{C}-\mathrm{H}$ (aromatic) & $1.084-1.085$ & $\mathrm{O} 34-\mathrm{C} 23-\mathrm{C} 26$ & 120.89 \\
\hline C - H (methyl) & $1.088-1.093$ & $\mathrm{O} 40$ - C27 - C26 & 122.52 \\
\hline $\mathrm{O} 39$ - H46 & 0.992 & $\mathrm{O} 40-\mathrm{C} 27-\mathrm{C} 28$ & 117.99 \\
\hline $\mathrm{O} 40$ - H45 & 0.995 & $\mathrm{O} 35-\mathrm{C} 29-\mathrm{C} 30$ & 118.02 \\
\hline $\mathrm{O} 35$ - H44 & 0.964 & $\mathrm{O} 35-\mathrm{C} 29-\mathrm{C} 30$ & 120.16 \\
\hline $\mathrm{O} 36$ - H43 & 0.964 & $\mathrm{O} 36-\mathrm{C} 12-\mathrm{C} 11$ & 118.02 \\
\hline $\mathrm{O} 37$ - H42 & 0.995 & $\mathrm{O} 36-\mathrm{C} 12-\mathrm{C} 13$ & 120.16 \\
\hline $\mathrm{O} 38$ - H41 & 0.992 & $\mathrm{O} 37-\mathrm{C} 14-\mathrm{C} 13$ & 117.99 \\
\hline $\mathrm{H} 46 \ldots \mathrm{O} 34$ & 1.657 & $\mathrm{O} 37-\mathrm{C} 14-\mathrm{C} 9$ & 122.52 \\
\hline $\mathrm{H} 45 \ldots \mathrm{O} 34$ & 1.639 & $\mathrm{O} 33-\mathrm{C} 8$ - C9 & 120.89 \\
\hline $\mathrm{H} 41 \ldots \mathrm{O} 33$ & 1.657 & $\mathrm{O} 33-\mathrm{C} 8-\mathrm{C} 4$ & 120.57 \\
\hline $\mathrm{H} 42 \ldots \mathrm{O} 33$ & 1.639 & $\mathrm{O} 38-\mathrm{C} 5-\mathrm{C} 4$ & 122.83 \\
\hline $\mathrm{C}-\mathrm{C}$ & $1.383-1.432$ & $\mathrm{O} 38$ - C5 - C6 & 118.15 \\
\hline Selected dihedral angles $\left({ }^{\circ}\right)$ & & $\mathrm{C} 47-\mathrm{C} 22-\mathrm{C} 17$ & 116.38 \\
\hline $\mathrm{C} 2-\mathrm{C} 21-\mathrm{C} 22-\mathrm{O} 47$ & -19.04 & $\mathrm{C} 47-\mathrm{C} 22-\mathrm{C} 21$ & 123.45 \\
\hline $\mathrm{C} 21-\mathrm{C} 2-\mathrm{C} 1-\mathrm{C} 51$ & -18.85 & $\mathrm{C} 51-\mathrm{C} 1-\mathrm{C} 2$ & 123.45 \\
\hline C11 - C30 - C29 - O35 & 14.61 & C51 - C1 - C6 & 116.39 \\
\hline C30 - C11 - C12 - O36 & 14.58 & Selected dihedral angles & \\
\hline C12 - C11 - C30 - C29 & 29.00 & O39 - C18 - C19 - C20 & 177.03 \\
\hline $\mathrm{C} 1-\mathrm{C} 2-\mathrm{C} 21-\mathrm{C} 22$ & -32.39 & $\mathrm{O} 34-\mathrm{C} 23-\mathrm{C} 26-\mathrm{C} 25$ & 175.59 \\
\hline $\mathrm{C} 1-\mathrm{C} 2-\mathrm{C} 3-\mathrm{C} 4$ & 15.78 & $\mathrm{O} 40-\mathrm{C} 27-\mathrm{C} 28-\mathrm{C} 29$ & 179.27 \\
\hline $\mathrm{C} 3-\mathrm{C} 2-\mathrm{C} 1-\mathrm{C} 51$ & 155.73 & $\mathrm{O} 35-\mathrm{C} 29-\mathrm{C} 30-\mathrm{C} 25$ & -159.09 \\
\hline C12 - C11 - C30 - C29 & 29.00 & $\mathrm{O} 36$ - C12 - C13 - C14 & 168.33 \\
\hline $\mathrm{C} 11-\mathrm{C} 12-\mathrm{C} 13-\mathrm{C} 14$ & -7.126 & $\mathrm{O} 37-\mathrm{C} 14-\mathrm{C} 9-\mathrm{C} 10$ & -177.33 \\
\hline C27 - C28 - C29 - C30 & -7.14 & $\mathrm{O} 33-\mathrm{C} 8-\mathrm{C} 4-\mathrm{C} 3$ & 8.85 \\
\hline $\mathrm{C} 20-\mathrm{C} 21-\mathrm{C} 22-\mathrm{C} 47$ & 155.59 & $\mathrm{O} 38-\mathrm{C} 5-\mathrm{C} 6-\mathrm{C} 1$ & -177.23 \\
\hline
\end{tabular}




\subsection{Vibrational Frequency Analyses}

Hypericin molecule consists of 54 atoms and accordingly it has 156 vibrational modes. In the following discussion, the hypericin molecule is experimentally examined and the experimental and theoretical vibrational frequencies, FT-IR intensities and assignments of hypericin are given in Table 2. The obtained and calculated FT-IR spectra of hypericin are given in Figure 2. As shown in Table 2, the obtained and calculated scaled FT-IR vibrational frequencies are consistent with each other. Harmonic frequencies, IR intensities and Raman activities are evaluated by DFT/B3LYP approach. Also, scaling factors were used between theoretical and experimental vibrational wavenumbers. The calculated (B3LYP / 6-311++G(d,p)) vibrational wavenumbers were scaled with 0.983 and 0.958 for frequencies lower and higher than $1700 \mathrm{~cm}^{-1}$, respectively $[32,33]$.

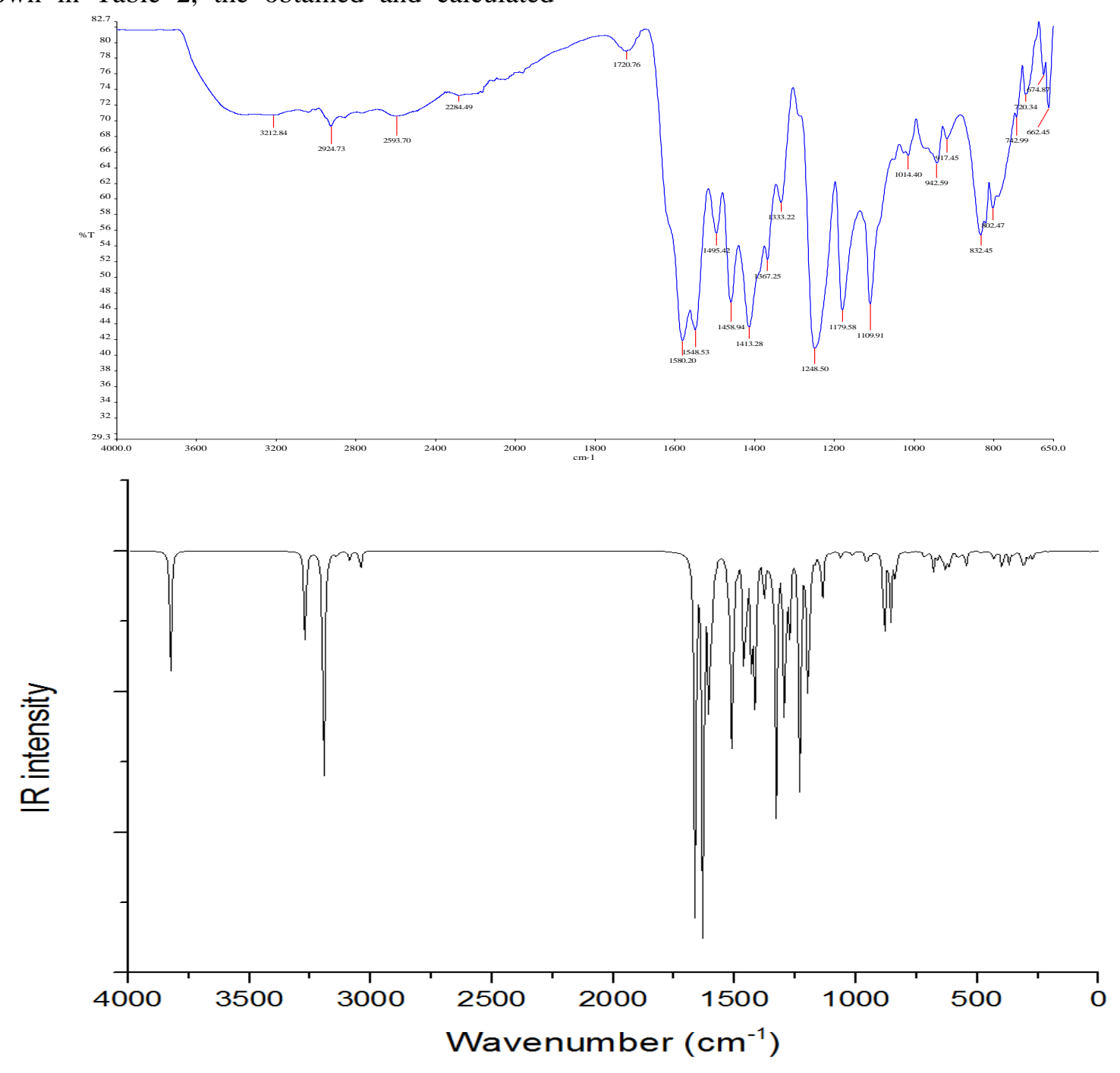

Figure 2. The observed (top) and theoretical (bottom) FT-IR spectra of hypericin

The spectral vibrational analysis was carried out depending on the characteristic vibrations of the methyl group, carbonyl group and hydroxyl group. $\mathrm{C}-\mathrm{H}, \mathrm{CH}_{3}, \mathrm{OH}, \mathrm{CO}, \mathrm{CC}, \mathrm{C} 22-\mathrm{C} 47$, and $\mathrm{C} 1-$ $\mathrm{C} 51$ vibrations are explained, respectively.
The aromatic C-H stretching bonds are assigned in the range 3100-3000 $\mathrm{cm}^{-1}$ [34]. The bands calculated at 3040.5, 3040.6, 3044.5 and 3044.6 $\mathrm{cm}^{-1}$ in IR spectrum can be assigned to the $\mathrm{CH}$ stretching vibrational modes in the molecule. The 
stretching vibrations (asymmetric) of $\mathrm{CH}_{3}$ were expected to be in the range of $3000-2905 \mathrm{~cm}^{-1}$ and stretching vibrations (symmetric) in 2870-2860 $\mathrm{cm}^{-1}$ range [35,36]. The experimental and calculated wavenumbers for stretching, scissoring, rocking and torsion modes for methyl groups are given in Table 2. In the present study, $\mathrm{CH}_{3}$ symmetric stretching in molecule appeared at $2925 \mathrm{~cm}^{-1}$ in FT-IR spectra and the related calculated scaled frequencies were 2912.1, 2915.2 $\mathrm{cm}^{-1} . \mathrm{CH}_{3}$ asymmetric stretching in the molecule appeared at $3010 \mathrm{~cm}^{-1}$ in FTIR and the related calculated scaled frequencies were 2956.5, $2961.3,3007.3,3009.2 \mathrm{~cm}^{-1}$. The symmetric and asymmetric bending vibrations of $\mathrm{CH}_{3}$ groups generally appear in $1465-1370 \mathrm{~cm}^{-1}$ region [37,38]. Symmetric bending vibration of $\mathrm{CH}_{3}$ was observed at 1413 and $1459 \mathrm{~cm}-1$ in its FT-IR spectrum. These calculated values are agreeable with the experimental FTIR values at 1406.1 and $1464.2 \mathrm{~cm}^{-1}$, respectively. The other symmetric bending vibration $\left(\delta_{\mathrm{s}} \mathrm{CH}_{3}\right)$ is calculated at 1387,4 $\mathrm{cm}^{-1}$. In B3LYP/6-311++G(d,p) calculation, the $\mathrm{CH}_{3}$ rocking vibrational modes were observed at scaled 752.2, 939.8, 1017.2, 1036.6, 1046.4, $\mathrm{cm}^{-1}$. These values are consistent with the experimental FT-IR values at 743, 943, 1014, 1029 and 1046 $\mathrm{cm}^{-1}$. Torsional vibration mode was observed at scaled $234.7 \mathrm{~cm}^{-1}$ by B3LYP / 6-311++G(d,p) calculation.

The vibrational modes of the $\mathrm{OH}$ group are inplane bending, stretching, and out-of-plane bending. The location of these species vary based on the extent of hydrogen bonding, as $\mathrm{OH}$ group vibrations exhibit the highest sensitivity to the environment. Free $\mathrm{OH}$ stretching modes result in sharp bands in $3700-3584 \mathrm{~cm}^{-1}$ region, and this stretching mode emerges between 3550 and 3200 $\mathrm{cm}^{-1}$ due to the intra-molecular and inter- molecular hydrogen bonding effect [39]. $\mathrm{OH}$ stretching mode appeared at $3212 \mathrm{~cm}^{-1}$ in FT-IR spectra and the related calculated scaled frequency was $3132.6 \mathrm{~cm}^{-1}$. The other calculated scaled frequencies for $\mathrm{OH}$ stretching mode were 3059.7, $3060.0,3132.8,3664.1,3664.3 \mathrm{~cm}^{-1}$.

Silverstein and Webster [40] reported that in phenol compounds absorption occurs in 1390$1330 \mathrm{~cm}^{-1}$ and $1260-1180 \mathrm{~cm}^{-1}$ region of $\mathrm{C}-\mathrm{O}$ vibrational bands. As shown in Table 2, the bands observed at 1046 and $1413 \mathrm{~cm}^{-1}$ and computed at 1046.4 and $1406.1 \mathrm{~cm}^{-1}$ are ascribed to the vibrational stretching modes between the carbon and oxygen $(\mathrm{O})$ atoms.

The CC stretching vibrations in aromatic ring generally emerge in the region $1400-1625 \mathrm{~cm}^{-1}$ [41]. As seen in Table 2, C-C stretching vibrations were theoretically calculated at $922.9-1604.1 \mathrm{~cm}^{-1}$. The wavenumbers of $\mathrm{C}-\mathrm{C}$ stretching vibrations were observed at $917-1605 \mathrm{~cm}^{-1}$ in the FT-IR spectrum. The bands observed at $662,675,802$, 917, 943, 974, 1046, 1091 and $1111 \mathrm{~cm}^{-1}$ and calculated at 658.1, 668.4, 796.5, 922.9, 939.8, 996.2, 1046.4, 1085.2, 1117.7 and $1147.4 \mathrm{~cm}^{-1}$ can be assigned to the in-plane bending (CCC) vibrations of the molecule. Also, the torsional $\mathrm{C}$ $\mathrm{C}-\mathrm{C}-\mathrm{C}$ modes are observed at $720 \mathrm{~cm}^{-1}$ and computed at $726.6 \mathrm{~cm}^{-1}$. The torsional, in-plane and out-of-plane bending vibrational modes for $\mathrm{H}$ $-\mathrm{C}-\mathrm{C}-\mathrm{C}, \mathrm{H}-\mathrm{O}-\mathrm{C}$ and $\mathrm{C}-\mathrm{C}-\mathrm{C}-\mathrm{C}$ (or $\mathrm{O}-$ $\mathrm{C}-\mathrm{C}-\mathrm{C}$ ) are presented in Table 2. In FTIR spectra, the bands at $662 \mathrm{~cm}^{-1}$ were experimentally assigned to $\mathrm{C}-\mathrm{C}-\mathrm{C}$ bending. The corresponding bending frequency (B3LYP/6$311++\mathrm{G}(\mathrm{d}, \mathrm{p}))$ is $658.1 \mathrm{~cm}^{-1}$. The calculated frequencies for $\mathrm{C} 22-\mathrm{C} 47\left(\mathrm{vC}-\mathrm{CH}_{3}\right)$ and $\mathrm{C} 1-\mathrm{C} 51$ $\left(v \mathrm{C}-\mathrm{CH}_{3}\right)$ are $1085.2 \mathrm{~cm}^{-1}$ and $1147.4 \mathrm{~cm}^{-1}$, respectively. 
Table 2. The observed and theoretical vibrational frequencies and assignments of hypericin

\begin{tabular}{|c|c|c|c|c|}
\hline \multirow{2}{*}{ Assignments } & \multirow{2}{*}{$\operatorname{Exp} . \operatorname{IR}\left(\mathrm{cm}^{-1}\right)$} & \multicolumn{3}{|c|}{ The calculated } \\
\hline & & Unscaled freq. & Scaled freq. & IR int. \\
\hline$\tau \mathrm{CH}_{3}$ & & 238,7 & 234,7 & 0,715 \\
\hline$\delta \mathrm{CCC}$ & 662 & 669,5 & 658,1 & 1,687 \\
\hline$\delta \mathrm{CCC}$ & 675 & 680,0 & 668,4 & 41,965 \\
\hline$\tau \mathrm{HCCC}+\gamma \mathrm{CCCC}$ & 682 & 695,3 & 683,5 & 0,160 \\
\hline$\tau \mathrm{HCCC}+\tau \mathrm{CCCC}$ & 720 & 739,2 & 726,6 & 0,184 \\
\hline$\gamma \mathrm{CCCC}+\gamma \mathrm{OCCC}+\rho \mathrm{CH}_{3}$ & 743 & 765,2 & 752,2 & 0,373 \\
\hline$\gamma \mathrm{OCCC}+\gamma \mathrm{CCCC}$ & & 781,4 & 768,1 & 1,870 \\
\hline$\gamma \mathrm{CCCC}$ & 785 & 787,8 & 774,4 & 0,860 \\
\hline$\delta \mathrm{CCC}$ & 802 & 810,2 & 796,5 & 0,107 \\
\hline$\tau \mathrm{HCCC}$ & 821 & 836,9 & 822,7 & 9,382 \\
\hline$\tau \mathrm{HCCC}$ & 832 & 838,8 & 824,5 & 42,609 \\
\hline$\tau \mathrm{HOCC}$ & & 856,3 & 841,8 & 124,335 \\
\hline$\tau \mathrm{HOCC}$ & & 860,5 & 845,9 & 11,809 \\
\hline$\tau \mathrm{HOCC}$ & & 882,9 & 867,9 & 193,225 \\
\hline$\tau \mathrm{HOCC}$ & & 887,5 & 872,4 & 3,348 \\
\hline$\delta \mathrm{CCC}+v \mathrm{CC}$ & 917 & 938,9 & 922,9 & 10,970 \\
\hline$\delta \mathrm{CCC}+\rho \mathrm{CH}_{3}+v \mathrm{CC}+\delta \mathrm{HCC}$ & 943 & 956,0 & 939,8 & 39,335 \\
\hline$\delta \mathrm{CCC}+v \mathrm{C}-\mathrm{CH}_{3}$ & 974 & 1013,4 & 996,2 & 12,463 \\
\hline$\rho \mathrm{CH}_{3}$ & & 1028,5 & 1011,0 & 1,939 \\
\hline$\rho \mathrm{CH}_{3}$ & 1014 & 1034,8 & 1017,2 & 1,421 \\
\hline$\rho \mathrm{CH}_{3}$ & 1029 & 1054,5 & 1036,6 & 2,080 \\
\hline$\rho \mathrm{CH}_{3}$ & & 1058,7 & 1040,7 & 2,567 \\
\hline$\rho \mathrm{CH}_{3}+\delta \mathrm{CCC}+v \mathrm{CO}+\delta \mathrm{HCC}$ & 1046 & 1064,5 & 1046,4 & 12,328 \\
\hline$v \mathrm{C}-\mathrm{CH}_{3}+\delta \mathrm{CCC}+v \mathrm{CC}+\delta \mathrm{HCC}+\delta \mathrm{HOC}$ & 1091 & 1104,0 & 1085,2 & 2,880 \\
\hline$v \mathrm{CC}+\delta \mathrm{CCC}+\delta \mathrm{HOC}$ & 1111 & 1137,0 & 1117,7 & 95,305 \\
\hline$v \mathrm{C}-\mathrm{CH}_{3}+\delta \mathrm{HCC}+v \mathrm{CC}+\delta \mathrm{CCC}+\delta \mathrm{HOC}$ & & 1167,3 & 1147,4 & 14,374 \\
\hline$\delta \mathrm{HCC}+\delta \mathrm{HOC}$ & 1180 & 1196,8 & 1176,5 & 446,101 \\
\hline$\delta \mathrm{HCC}$ & & 1208,3 & 1187,8 & 1,091 \\
\hline$\delta \mathrm{HCC}+\delta \mathrm{HOC}$ & 1249 & 1273,7 & 1252,0 & 169,956 \\
\hline$\delta \mathrm{HOC}+\delta \mathrm{HCC}+v \mathrm{CC}$ & 1280 & 1276,9 & 1255,2 & 28,966 \\
\hline$\nu \mathrm{CC}+\delta \mathrm{HOC}$ & 1333 & 1357,7 & 1334,6 & 15,027 \\
\hline$\nu \mathrm{CC}+\delta \mathrm{HCC}+\delta \mathrm{HOC}$ & 1367 & 1393,1 & 1369,4 & 2,320 \\
\hline$\delta_{\mathrm{s}} \mathrm{CH}_{3}$ (sym. bend.) & & 1411,4 & 1387,4 & 19,186 \\
\hline$v \mathrm{CC}+v \mathrm{CO}+\delta_{\mathrm{s}} \mathrm{CH}_{3}$ (sym. bend.) & 1413 & 1430,5 & 1406,1 & 233,424 \\
\hline$\delta_{\mathrm{s}} \mathrm{CH}_{3}+\delta \mathrm{HOC}$ & 1459 & 1489,5 & 1464,2 & 27,145 \\
\hline$v \mathrm{CC}+\delta \mathrm{HCC}+\delta \mathrm{HOC}$ & 1495 & 1525,0 & 1499,0 & 58,428 \\
\hline$v \mathrm{C}=\mathrm{O}+v \mathrm{CC}+\delta \mathrm{HOC}$ & 1549 & 1579,0 & 1552,2 & 28,583 \\
\hline$v \mathrm{CC}+\delta \mathrm{HOC}$ & 1580 & 1608,4 & 1581,1 & 254,658 \\
\hline$v \mathrm{CC}+\delta \mathrm{HOC}$ & 1605 & 1631,9 & 1604,1 & 122,597 \\
\hline$v_{\mathrm{s}} \mathrm{CH}_{3}$ & & 3039,8 & 2912,1 & 6,738 \\
\hline$v_{\mathrm{s}} \mathrm{CH}_{3}$ & 2925 & 3043,0 & 2915,2 & 42,496 \\
\hline$v_{a s} \mathrm{CH}_{3}$ & & 3086,2 & 2956,5 & 17,722 \\
\hline$v_{\text {as }} \mathrm{CH}_{3}$ & & 3091,1 & 2961,3 & 6,108 \\
\hline$v_{\mathrm{as}} \mathrm{CH}_{3}$ & & 3139,1 & 3007,3 & 1,399 \\
\hline $\mathrm{Vas}_{\mathrm{S}} \mathrm{CH}_{3}$ & 3010 & 3141,2 & 3009,2 & 10,378 \\
\hline$v \mathrm{CH}$ & & 3173,8 & 3040,5 & 1,324 \\
\hline$v \mathrm{CH}$ & & 3173,9 & 3040,6 & 4,648 \\
\hline$v \mathrm{CH}$ & & 3178,0 & 3044,5 & 3,896 \\
\hline$v \mathrm{CH}$ & & 3178,1 & 3044,6 & 3,393 \\
\hline vOH & & 3193,8 & 3059,7 & 68,247 \\
\hline$v \mathrm{OH}$ & & 3194,2 & 3060,0 & 526,743 \\
\hline$v \mathrm{OH}$ & 3212 & 3269,9 & 3132,6 & 128,651 \\
\hline $\mathrm{vOH}$ & & 3270,1 & 3132,8 & 98,185 \\
\hline $\mathrm{vOH}$ & & 3824,7 & 3664,1 & 63,655 \\
\hline vOH & & 3825,0 & 3664,3 & 196,281 \\
\hline
\end{tabular}


Showalter et al. performed the ab initio quantum mechanical calculations of the normal form of hypericin and reported the calculated frequencies of normal mode vibrations of hypericin species [42]. The scaled vibrational modes in this spectral region for ground state singlet ("normal" form) oscillator(s) were within the range of 1102-1612 $\mathrm{cm}^{-1}$ [42]. In the same study, the time-resolved infrared data obtained on the microsecond time scale for hypericin was within the range of 1300 $1628 \mathrm{~cm}^{-1}$, which is consistent with those of the present research.

\subsection{HOMO-LUMO Analyses}

The highest and the lowest occupied molecular orbitals are also referred to as the frontier molecule orbitals [43]. HOMO and LUMO energy band gap is an important factor in determination of molecular electrical properties [44]. HOMO indicates the electron-donating capability and LUMO presents the electron accepting capability of a molecule [45].

In our study, the simulated HOMO and LUMO surfaces, energy values and their shapes for the title molecule are given in Figure 3. The calculated HOMO and LUMO energy values are $-5.774 \mathrm{eV}$ and $-3.221 \mathrm{eV}$ respectively at the DFT / B3LYP / 6-311++G(d,p). The energy gap between HOMO and LUMO is computed at $2.553 \mathrm{eV}$. The HOMO is localized on the groups excluding O33, $\mathrm{C} 8, \mathrm{C} 7, \mathrm{C} 24, \mathrm{C} 23, \mathrm{O} 34$, hydrogen atoms and methyl groups, while the LUMO is placed on overall molecular structure except methyl groups and hydrogen atoms.
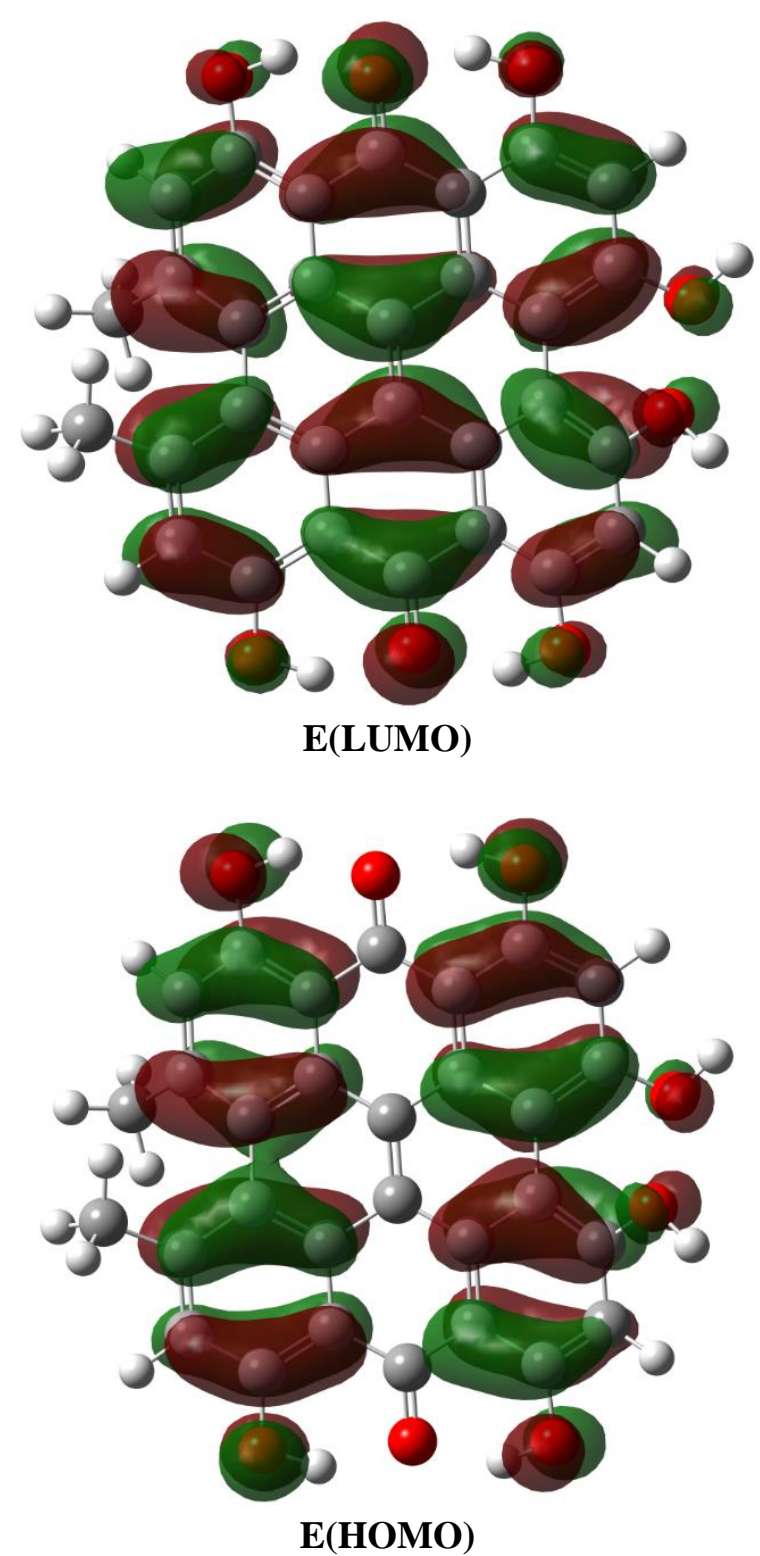

Figure 3. The simulated HOMO (-5.774 eV) and LUMO $(-3.221 \mathrm{eV})$ surfaces and energy values of hypericin

\subsection{Molecular Electrostatic Potential}

MEP is an important indicator to understand the molecular interactions [46]. MEP is associated with the total electronic density, and it is an important indicator in understanding the locations of nucleophilic reactions and electrophilic attack. For the studied systems the MEP values were evaluated as previously explained using the equation [47-49].

$$
V(\vec{r})=\sum_{A} \frac{Z_{A}}{\left|\vec{R}_{A}-\vec{r}\right|}-\int \frac{\rho\left(\vec{r}^{\prime}\right)}{\left|\vec{r}^{\prime}-\vec{r}\right|} d \vec{r}^{\prime}
$$


where $Z_{A}$ is the charge of nucleus $A, \rho\left(\vec{r}^{\prime}\right)$ is the charge density at $\vec{r}^{\prime}$, and $\vec{r}^{\prime}$ is the integration variable. $V(\vec{r})$ electrostatic potential at any point of a molecule is given by the electrostatic potential equation.

Negative, positive and zero electrostatic potential regions are shown with red, blue and green colors, respectively. The negative regions surround the oxygen atoms (O37, O38, O39 and O40) that contain the hydroxyl group $(\mathrm{OH})$. The positive electrostatic potential regions are localized around the other aromatic and methyl hydrogen atoms, particularly H43 and H44 atoms (Figure 4).

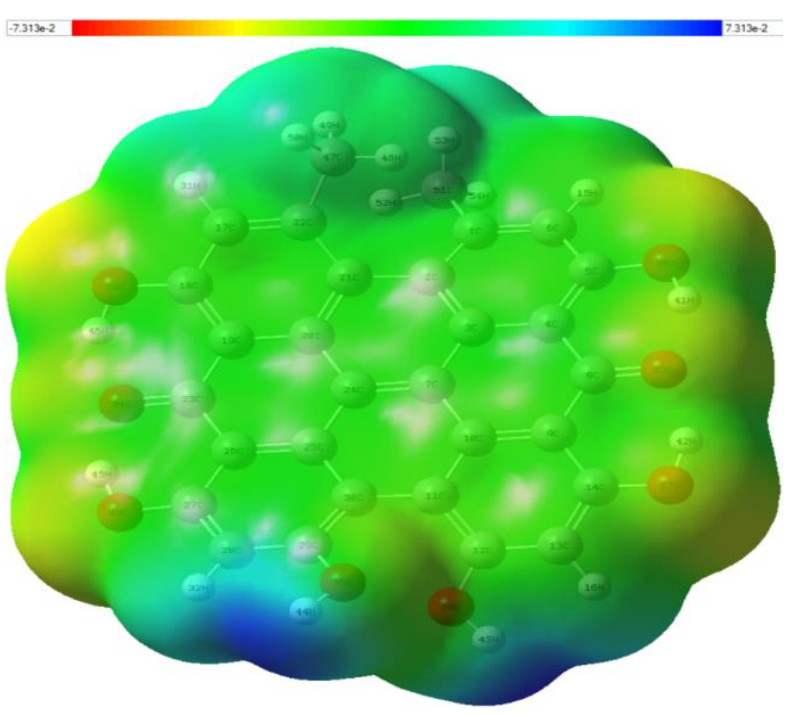

Figure 4. The simulated MEP map.

\section{CONCLUSION}

In this study, the molecular structure and the vibrational frequencies of the hypericin molecule were examined. The assigned frequencies were investigated in consideration of the computed and the experimental FT-IR analysis results. The HOMO, LUMO and MEP analyses were performed to determine electronic charge transfer, energy band gap, electrophilic and nucleophilic sites (or negative and positive electrostatic regions) and charge distribution of the hypericin molecule. Computed vibrational frequencies and assignments are consistent with the experimental FT-IR values obtained in this study.

\section{REFERENCES}

[1]. Kasper S., Caraci F., Forti B., Drago F., Aguglia E., Efficacy and tolerability of Hypericum extract for the treatment of mild to moderate depression. Eur Neuropsychopharmacol 2010; 20: 747-65.

[2]. Butterweck V., Mechanism of action of St John's wort in depression: what is known? CNS Drugs 2003; 17(8): 539-62.

[3]. Bongiorno P., LoGiudice P., Hypericum for Depression. Nat Med J 2010; 2(12).

[4]. Mattace Raso G., Pacilio M., Di Carlo G., Esposito E., Pinto L., Meli R., In-vivo and in-vitro anti-inflammatory effect of Echinacea purpurea and Hypericum perforatum. J Pharm Pharmacol 2002; 54: 1379-83.

[5]. Sosa S., Pace R., Bornancin A., Morazzoni P., Riva A., Tubaro A., et al., Topical antiinflammatory activity of extracts and compounds from Hypericum perforatum $\mathrm{L}$. J Pharm Pharmacol 2007; 59: 703-9.

[6]. Galeotti N., Vivoli E., Bilia A.R., Bergonzi M.C., Bartolini A., Ghelardini C., A prolonged protein kinase $\mathrm{C}$-mediated, opioid-related antinociceptive effect of $\mathrm{St}$ John's Wort in mice. J Pain 2010; 11: 14959.

[7]. Galeotti N., Vivoli E., Bilia A.R., Vincieri F.F., Bartolini A., Ghelardini C., St John's Wort relieves neuropathic pain through a hypericin-mediated inhibition of the protein kinase $\mathrm{C} \gamma$ and $\varepsilon$ activity. Biochem Pharmacol 2010; 79: 1327-36.

[8]. Lee J. Y., Duke R. K., Tran V. H., Hook J. M., Duke C. C., Hyperforin and its analogues inhibit CYP3A4 enzyme activity. Phytochemistry 2006; 67: 2550-60.

[9]. Siskos M. G., Choudhary M. I., Tzakos A. G., Gerothanassis I. P., ${ }^{1} \mathrm{H}$ NMR chemical shift assignment, structure and conformational elucidation of hypericin with the use of DFT calculations - The challenge of accurate positions of labile hydrogens. Tetrahedron 2016; 72: 8287-93.

[10]. Öztürk N., Korkmaz S., Öztürk Y., Woundhealing activity of St. John's Wort 
(Hypericum perforatum L.) on chicken embryonic fibroblasts. J Ethnopharmacol 2007; 111: 33-9.

[11]. Zhang W., Gong X., Cai Y., Zhang C., Yu X., Fan J., Diao Gu., Investigation of watersoluble inclusion complex of hypericin with $\beta$-cyclodextrin polymer. Carbohydrate Polymers 2013; 95: 366-70.

[12]. Arsić I., Preparation and Characterization of St. John's Wort Herb Extracts Using Olive, Sunflower and Palm Oils. Acta facultatis medicae Naissensis 2016;33(2): 119-26.

[13]. Gîtea D., Şipoş M., Mircea T., Paşca B., The analysis of alcoholic extracts of hypericum species by UV/VIS spectrophotometry. Analele Universităţii din Oradea - Fascicula Biologie Tom. 2010; 17 (1): 111-5.

[14]. Derun, E. Moroydor., Eslek, Z., Piskin, S., Extraction and Analysis of Hypericum perforatum L. from Turkey. Int J Chem, Mol, Nucl, Mater Metal Eng 2013; 7 (7).

[15]. Nikolic G. S., Zlatkovic S. Z., Assaying the variation in secondary metabolites of St.John's wort for its better use as an antibiotic. J Med Plants Res 2010; 4(3): 211-24.

[16]. Hasanein P., Shahidi S., Effects of Hypericum perforatum Extract on Diabetesinduced Learning and Memory Impairment in Rats., Phytother. Res. 2011; 25: 544-9.

[17]. Schwob I., Bessiere J.M., Viaro J., Composition of the essential oils of Hypericum perforatum L. from southeastern Franca. C.R.Biologies 2002; 325: 781-5.

[18]. Orcic D. Z., Mimica-Dukic N. M., Franciskovic M. M., Petrovic S. S., Jovin E. D., Antioxidant activity relationship of phenolic compounds in Hypericum perforatum L. Chem Centr J 2011; 5: 34.

[19]. Andersen D. O., Weber N. D., Wood S. G., Hughes B. G., Murray B. K., North. J. A., In vitro virucidal activity of selected anthraquinones and anthraquinone derivatives. Antiviral Res 1991; 16(2): 18596.
[20]. Barnard D. L., Huffman J. H., Morris J. L., Wood, S. G., Hughes B. G., Sidwell R. W., Evaluation of the antiviral activity of anthraquinones, anthrones and anthra quinone derivatives against human cytomegalovirus. Antiviral Res 1992; 17 : 63-77.

[21]. Pavlovic M., Tzakou O., Petrakis P.V., Couladis M., The essential oil of Hypericum perforatum L., Hypericum tetrapterum Fries, Hypericumolympicum L. growing in Greece. Flav Fragr J 2006; 21 : 84-7.

[22]. Wölfle U., Seelinger G., Schempp C. M., Topical Application of St. John's Wort (Hypericum perforatum). Planta Med 2014; 80: 109-20.

[23]. Becke A.D. Density-functional thermochemistry. III. The role of exact exchange, J. Chem. Phys. 1993; 98: 564852.

[24]. Lee C., Yang W., Parr R.G. Development of the Colle-Salvetti correlation-energy formula into a functional of the electron density, Phys Rev 1988; B 37: 785-9.

[25]. Frish A., Nielsen A. B., Holder A. J., Gauss View User Manual, Gaussian Inc., Pittsburg, PA, 2001.

[26]. Frisch M.J., Trucks G.W., Schlegel H.B., et al., Gaussian 09, Revision, A.1, Gaussian Inc., Wallingford CT, 2009.

[27]. Gaussian website, Visualizing Molecules\&Reactions with Gaussview 5. Available at: http://www.gaussian.com/g_prod/gv5.htm. Retrieved August 102016.

[28]. Shankar R.Y.B., Prasad M.V.S., Udaya S.N., Veeraiah V. Vibrational (FT-IR, FTRaman) and UV-Visible spectroscopic studies, HOMO-LUMO, NBO, NLO and MEP analysis of Benzyl (imino $(1 \mathrm{H}-$ pyrazol-1-yl) methyl) carbamate using DFT calculaions, J Mol Str 2016; 1108: 567-82.

[29]. Keresztury G., Holly S., Besenyei G., Varga J., Wang A., Durig J.R. Vibrational spectra of monothiocarbamates-II. IR and Raman spectra, vibrational assignment, conformational analysis and ab initio 
calculations of S-methyl-N,Ndimethylthiocarbamate, Spectro Acta A 1993; 49: 2007-2017.

[30]. Keresztury G., in: Chalmers J.M., Griffith P.R. (Eds), Raman Spectroscopy: Theory in Hand book of Vibrational Spectroscopy, Vol. 1, New York: John Wiley \& Sons Ltd., 2002.

[31]. Chocholousova J., Vladimir S.V. Hobza P., First local minimum of the formic acid dimer exhibits simultaneously red-shifted $\mathrm{O}-\mathrm{H} \cdots \mathrm{O}$ and improper blue-shifted $\mathrm{C}-$ $\mathrm{H} \cdot \cdots \mathrm{O}$ hydrogen bonds, Chem Phys 2004; 6: 37-41.

[32]. Sundaraganesan N., Ilakiamani S., Saleem H., Wojciechowski P. M., Michalska D., Spectrochim. Acta A 2005; 61: 2995-3001.

[33]. Gökçe H., Öztürk, N., Taşan, M., Bingöl Alpaslan, Y., Alpaslan, G. Spectroscopic characterization and quantum chemical computations of the 5-(4-pyridyl)-1H-1,2,4triazole-3-thiol molecule, Spectroscopy Letters 2016; 49, 167-179.

[34]. Patel U. H., Gandhi S.A., Patel B. D., Modh R.D., Patel R.H., Yadav J., Desai K. R., Synthesis, characterizations, molecular structure and DFT studies of 4-benzylidene2-(2-chloro-phenyl)-5-methyl-2,4-dihydropyrazol-3-one. Ind J Pure \& Appl Phys 2013; 51: 819-26.

[35]. Roeges N.P.G., A Guide to the Complete Interpretation of Infrared Spectra of Organic Structures, New York: Wiley, 1994.

[36]. Ambujakshan K.R., Madhavan V.S., Varghese H.T., Panicker C.Y., Temiz A. O., Tekiner G. B., Yildiz I., Spectrochim Acta 2008; 69A: 782.

[37]. Varsanyi G., Assignments for Vibrational Spectra of Seven Hundred Benzene Derivatives, Vol. I \& II, Budapest: Academic Kiaclo, 1973.

[38]. Smith B., Infrared Spectral Interpretation-a Systematic Way, CRC press, New York, 1999.

[39]. Silverstein R. M., Webster F. X., Spectroscopic Identification of Organic
Compound, John Willey \& Sons, New York, 1998.

[40]. Silverstein R.M., Webster F.X., Spectroscopic Identification of Organic Compound, sixth ed., John Willey \& Sons, New York, 1998.

[41]. Sudha S., Sundaraganesan N., Vanchinathan K., Muthu K., Meenakshisundaram S.P. Spectroscopic (FTIR, FT-Raman, NMR and UV) and molecular structure investigations of 1,5diphenylpenta-1,4-dien-3-one: A combined experimental and theoretical study, J Mol Struct 2012; 1030: 191-203.

[42]. Showalter B. M., Datta, A., Chowdhury P. K., Park J., Bandyopadhyay P., Choudhury P. K., Kesavan S., Zeng Y., Kraus G. A., Gordon M. S., Toscano J. P., Petrich, J. W., Identification of a Vibrational Frequency Corresponding to $\mathrm{H}$-atom Translocation in Hypericin, Photochem. And Photobio. 2001; 74(2): 157-163.

[43]. Fukui K. Role of frontier orbitals in chemical reactions, Science 1982; 218: 747 54.

[44]. Pearson R.G. Absolute electronegativity and hardness correlated with molecular orbital theory, Proceed Natl Acad Sci.USA 1986; 83: 8440-41.

[45]. Asadi Z., Esrafili M.D., Vessally E. Asnaashariisfahani M., Yahyaei S., Khani A., A structural study of fentanyl by DFT calculations, NMR and IR spectroscopy, J Mol Str 2017; 1128: 552-62.

[46]. Murray J. S., Sen K., Molecular Electrostatic Potentials Concepts and Applications, Elsevier Science B.V., Amsterdam, The Netherlands, 1996.

[47]. Scrocco E., Tomasi J. Electronic molecular structure, reactivity and intermolecular forces: an euristic interpretation by means of electrostatic molecular potentials, J. Adv. Quantum Chem 1978; 11: 115-193.

[48].Luque F.J., Lopez J.M., Orozco M. Perspective on "Electrostatic interactions of a solute with a continuum. A direct utilization of ab initio molecular potentials 
for the prevision of solvent effects", Theoret Chem Acc 2000; 103: 343-5.

[49]. Politzer P., Murray J. The fundamental nature and role of the electrostatic potential in atoms and molecules, Theor Chem Acc 2002; 108: 134-42. 